countries are applying aggressive policies to recruit $\mathrm{PhD}$ holders, while developing countries have not yet substantially improved the working conditions offered. Mexico has adopted quality assurance policies, and, recently, pilot initiatives for the convergence of higher education systems, international harmonization of domestic degrees, regional equivalency in professional training - in the framework of bilateral or multilateral agreements, such as NAFTA. Consequently, the recruitment of Mexican postgraduates regardless of where their degrees were obtained, has become less risky for international employers. Those factors point to a scenario in which white collar migration will rapidly increase.

The situation described above calls for strategic decisions. One decision would have to involve national postgraduate scholarships. Mexico is providing funding for doctoral students in fields with a greater probability of obtaining employment abroad than of returning home. Another factor is the reestablishment of strategic linkages with scientific and productive communities abroad, based on the results achieved in Argentina, Colombia, El Salvador, and Venezuela, as well as in South Africa, China, and India. Still another area involves a science policy more focused on national priorities and on the expansion and reproduction of scientific communities and entrepreneurial groups. The goal is that the relations with Mexicans living abroad will help to consolidate an official program for the reform of a national science system.

\section{Transformation, Reform, and Renewal in Afghanistan}

\section{William G. Tierney}

William G. Tierney is Wilbur Kieffer Professor of Higher Education and director of the Center for Higher Education Policy Analysis at the University of Southern California. Address: Waite Phillips Hall, Univ. of Southern California, Los Angeles, CA goo89, USA. E-mail: wgtiern@usc.edu.

A fghan higher education is undergoing enormous changes after a generation fraught with conflict, university closure, and severe damage to the infrastructure of Afghanistan's universities. Postsecondary institutions have suffered from several significant problems over the past quarter century. Many of the most talented faculty fled the country-first during the Soviet invasion, then during the years of fighting by the Mujahidin, and most recently during the era of the Taliban. Faculty who stayed in the country suffered from professional isolation not only with peers outside Afghanistan but also with colleagues at other institutions within Afghanistan. Many faculty were killed or exiled; others were driven underground. Higher education became highly politicized, ideologized, and sectarianized. Postsecondary campuses became war zones.
The result was that the infrastructure was damaged, looted, or destroyed.

\section{The Infrastructure of the System}

Afghanistan's higher education system remains one of the most centralized in the world, although a weakened or nonexistent infrastructure limits the capacity to manage the system. Such centralization permits standardized policies and procedures, but it also weakens the authority and innovativeness of the chancellors and faculty on the ig campuses. Universities do not have budgets, and all requests involving income, hiring, and new departments must be requested through the Ministry of Education. Students are accepted not by the respective universities but by the ministry. The ministry also determines the size and placement of an incoming class.

The ministry controls the budgets for all postsecondary institutions with a total annual operating budget of slightly more than US\$9 million. About 65 percent of the budget covers the costs of housing and feeding students in dormitories. Tuition is not charged at any university. The result is that postsecondary institutions are dependent upon the largesse of nongovernmental organizations for structural improvements.

The number of institutions-currently ig four-year institutions and I8 two-year institutions (which are equivalent to teacher training institutes) - has continued to expand, resulting in considerable discussion about the inefficiencies within the system. Some institutions are quite small, with fewer than 500 students, and their capacity to increase is limited due to their geographic isolation. At the same time, Afghanistan currently has less than 0.15 percent of its population in higher education, a statistic among the lowest in the world. There are currently 36,000 undergraduate students, I7 percent of whom are women. The estimate is that within five years over 100,000 students will desire a postsecondary education. The system is not well positioned to deal with such a rapid expansion. In addition to the physical devastation suffered by many campuses, during the Taliban regime hundreds of thousands of books were destroyed. No university presently has what might be considered a minimally acceptable number of books for a postsecondary library. Buildings remain in serious need of repair. No institution has more than roo computers.

\section{The Diversity of the Population}

The challenged infrastructure must respond to the needs of a culturally and ethnically diverse population. There are four major ethnic groups in the country and two major languages. The diversity of cultures is a social fact that is to be honored; at the same time, given the recent history of the country, language and culture are also significant topics of contestation. Which language is to be used as the medium of instruction, for example, is an unsettled question with many different answers. Although English is the most widely spoken foreign language in Afghanistan, the extent of Afghans' fluency varies widely. 
Hopeful signs do exist for higher education in Afghanistan. In the last four years, over 2,500,000 refuges from neighboring countries have returned to the country, one of the largest repatriation movements in modern history. Many of these refugees are children. Along with hundreds of thousands of children who remained in Afghanistan and were denied schooling under the Taliban-including, of course, girls-students are now flocking to schools. With the encouragement of the ambitious Back to School Program, the last two years have seen millions of children pour into elementary and secondary schools, as citizens embrace education as a path to a better future. The challenge for higher education is to accommodate this influx of students over the next decade. Issues to be resolved include language of instruction, curriculum, and degree standards. Funding to support institutions must be procured. And faculty must be able to respond to student demand, institutional needs, and the national context.

\section{Challenges Facing Faculty}

As with many professional sectors in the country, the events of the past 25 years have profoundly affected the professoriate. At present, the postsecondary system has approximately 2,200 faculty in four-year institutions. Slightly more than 50 percent have a bachelor's degree, less than 6 percent hold a doctorate, and 12 percent of the faculty are female. The problematic state

\section{The challenge of higher education is to accommo- date this influx of students over the next decade.}

of the academic profession in Afghanistan has had a serious impact. First, early in their careers faculty have no sense of what it means to be an academic. Second, senior faculty base their understanding of what it means to be an academic from experiences of over a quarter century ago. Third, faculty in general have limited expectations of their colleagues and evince no sense of ownership over critical matters such as academic freedom, curriculum development, faculty-student relationships, or intended outcomes for degree programs. Finally, the professoriate is no longer viewed as a respected calling but instead is a poorly paid civil service job.

This state of affairs is demonstrated in numerous ways. No university offers a master's or doctoral degree. Students complain that most instruction stifles creativity and critical thinking. Faculty show little respect for student opinion; indeed, if a student challenges a faculty member in class or disagrees with a professor's point of view, students run the risk not only of having their class grade lowered but also being threatened with retribution, even violence. Unacceptable behavior such as nepotism, bribery, plagiarism, and sexual harassment have been reported as commonplace. Academic freedom is absent. Students and faculty can be disciplined for exercising free speech. By no means do all faculty exhibit such aberrant behavior. However, the related problem is that there are no accepted standards to deal with this sort of behavior.

Regardless of the shortcomings of graduate education in developed countries, it is commonplace to assume that when students complete their graduate training, they have learned a professional ethic about what it means to be an academic. When an individual assumes a faculty position, that ethic is further called upon in the specific institution, college, and department. Such training has been largely absent in Afghanistan for 25 years. One ought not to be surprised at the current conditions. A professional ethic of the faculty is not something that arises without explicit cultivation.

\section{CONCLUSION}

Clearly, a great deal of work awaits those who desire to improve higher education in Afghanistan. At the same time, one ought not to forget the progress made since the fall of the Taliban in December 200I. Buildings that were closed are now open. Faculty who were silenced have returned to the classroom. The explosion in applications for college is evidence on the part of the young of their desire to learn. Indeed, the university students resemble college-age students everywhere-showing energetic, inquisitive, optimistic, and impatient attitudes.

Everyone acknowledges that the problems in higher education will not be resolved overnight. Indeed, without consistent and significant external support, and the willingness within Afghanistan to restructure the system, the road will be very long. But education has long been considered a way out and a way up. For Afghanistan to put in place an indigenous model of what they want to be as a nation, then the universities will have to play a major role. Without a functioning higher education system, it will be impossible to generate the expertise and knowledge needed to rebuild a country with a vast history and troubled past.

\section{Ten Years: The Center for International Higher Education and International Higher} Education

\section{Philip G. Altbach}

Philip G. Altbach is Monan professor of higher education and director of the Center for International Higher Education at Boston College.

The Center for International Higher Education (CIHE) and 1 its flagship publication, International Higher Education (IHE), are entering their 11th year of activity in 2005. It is appropriate to look at what has been accomplished and how higher education has changed in the past decade. We started 